Plasma proteomics of biomarkers for inflammation or cancer cannot predict relapse in chronic myeloid leukaemia patients stopping tyrosine kinase inhibitor therapy

\title{
Soderlund, Stina
}

2020-03

Soderlund, S, Persson , I, llanderd, M , Guilhot, J , Hjorth-Hansen , H , Koskenvesa , P , Richter , J , Saussele , S , Mustjoki , S \& Olsson-Strömberg, U 2020 , ' Plasma proteomics of biomarkers for inflammation or cancer cannot predict relapse in chronic myeloid leukaemia patients stopping tyrosine kinase inhibitor therapy ', Leukemia Research, vol. 90 , 106310 . https://doi.org/10.1016/j.leukres.2020.106310

http://hdl.handle.net/10138/325108

https://doi.org/10.1016/j.leukres.2020.106310

cc_by_nc_nd

acceptedVersion

Downloaded from Helda, University of Helsinki institutional repository.

This is an electronic reprint of the original article.

This reprint may differ from the original in pagination and typographic detail.

Please cite the original version. 


\title{
Plasma proteomics of biomarkers for inflammation or cancer cannot predict relapse in chronic myeloid leukaemia patients stopping tyrosine kinase inhibitor therapy
}

\author{
Stina Söderlund ${ }^{1,2}$, Inger Persson ${ }^{3}$, Mette Ilander ${ }^{4,5}$, Joëlle Guilhot ${ }^{6}$, Henrik Hjorth-Hansen ${ }^{7}$, Perttu \\ Koskenvesa ${ }^{4}$, Johan Richter ${ }^{8}$, Susanne Saussele ${ }^{9}$, Satu Mustjoki ${ }^{4,5}$, Ulla Olsson-Strömberg ${ }^{1,2}$ \\ ${ }^{1}$ Department of medical sciences, Uppsala University, Uppsala, Sweden; ${ }^{2}$ Section of Hematology, Uppsala University \\ Hospital, Uppsala, Sweden; ${ }^{3}$ Department of Statistics, Uppsala University, Uppsala, Sweden; ${ }^{4}$ Hematology Research Unit \\ Helsinki, University of Helsinki and Helsinki University Hospital Comprehensive Cancer Center, Helsinki, Finland; \\ ${ }^{5}$ Department of clinical chemistry and Hematology, University of Helsinki, Finland; Institut National de la Santé et de la \\ Recherche Medicale (INSERM), CHU de Poitiers, Poitiers, France; ${ }^{7}$ Department of Hematology, St Olav's Hospital, \\ Trondheim, Norway; ${ }^{8}$ Department of Hematology, Oncology and Radiation Physics, Skåne University Hospital, Lund, \\ Sweden; ${ }^{9}$ III. Medizinische Klinik, Universitätsmedizin Mannheim, Universität Heidelberg, Mannheim, Germany
}

\begin{abstract}
Several studies have now shown that chronic myeloid leukaemia (CML) patients in deep molecular remission may discontinue tyrosine kinase inhibitor (TKI) treatment with a treatment free remission (TFR) rate of approximately $40-60 \%$. Some factors influencing the possibility of TFR have been described but better tools are needed for individual prediction of long-term TFR. Herein, two multiplex panels were utilised to analyse a total of 162 different plasma proteins from 56 patients included in the TKI stopping trial EURO-SKI. ${ }^{1}$ The purpose was to identify possible plasma protein markers for prediction of successful TKI discontinuation and to evaluate effects of TKI discontinuation on plasma protein profiles. No protein biomarkers sampled before TKI discontinuation could separate relapse cases from non-relapse cases but some plasma proteins differed between patients who relapsed and those who remained in TFR when followed over time after TKI cessation. In conclusion, the plasma protein markers in this study could not predict relapse after TKI discontinuation but may be of use to understand the mechanisms involved in maintenance of TFR.
\end{abstract}

\section{Keywords}

chronic myeloid leukemia; tyrosine kinase inhibitor; treatment free remission; proteomics; immunology

\section{Introduction}

Chronic myeloid leukaemia (CML) is a chronic myeloproliferative disorder arising due to the formation of a constitutively active tyrosine kinase (Bcr-Abl) through a translocation between chromosomes 9 and 22 in hematopoetic stem or progenitor cells. ${ }^{2}$ Treatment with inhibitors of the Bcr-Abl (tyrosine kinase inhibitors, TKIs) has during the last two decades drastically improved CML prognosis. ${ }^{3-6}$ However, long term TKI treatment is associated with high costs and severe adverse effects such as cardiovascular events. ${ }^{7}$ During recent years, several studies have shown that a proportion of TKI-treated patients who achieve optimal treatment responses ( $\mathrm{MR}^{4}$, i.e. $\geq 4$ log reduction in $B C R-A B L 1 ; B C R-A B L 1 \leq 0.01 \%$, or better) may discontinue treatment and remain in treatment-free remission (TFR) (reviewed $\mathrm{in}^{8}$ ). It is not fully known what factors influence the probability of TFR but so far, reports suggest that duration of TKI treatment and deep molecular response (DMR) before TKI stop influence the chances of remaining in TFR. ${ }^{1}$ Also, factors related to the patients' immune status seem to be of importance. ${ }^{9-11}$ Recently described factors of potential significance for TFR are genetic variants discovered by whole-exome sequencing ${ }^{12}$ and telomere- 
length shortening. ${ }^{13}$ However, there is still need for better prediction tools for choosing the right patients for stopping attempts. Easily accessible biomarkers such as plasma proteins would be a valuable complement for guiding decision making when TKI stopping attempts are moved in to clinical routine in the management of CML patients.

We have previously shown that plasma proteomics are feasible and useful in CML patients, both for studying patterns of protein expression and for identifying single proteins differentially expressed before and after TKI treatment initiation. ${ }^{14}$ In the present paper, we use a proximity extension assay (PEA)-based proteomic platform to study protein expression in a patient cohort from the large TKI stopping study EURO-SKI. ${ }^{1}$ We studied a total of 162 plasma proteins in TKI-treated patients $(n=56)$ before, at one and six months after TKI cessation, and at relapse with the primary aim of finding plasma protein markers predicting a successful treatment stop by comparing the markers between patients with and without relapse.

\section{Materials and methods}

\subsection{Patients and samples}

The study was conducted as an exploratory sub-study of the European Stop Tyrosine Kinase Inhibitor Study (EURO-SKI) (ClinicalTrials.gov identifier: NCT01596114). The patients included ( $n=56$, age range 18-78 years) were from Finland, Norway and Sweden. All were in chronic phase and had been treated with TKIs for at least three years prior to inclusion in the study. As outlined in the EURO-SKI inclusion criteria, all patients had sustained $D M R\left(M R^{4.0}\right)$ for at least one year before TKI cessation. Relapse was defined as loss of major molecular response (MMR; $B C R-A B L \leq 0.1 \%$ on the international scale). Peripheral blood samples were obtained at baseline (immediately prior to TKI cessation), at one and six months after stopping TKIs, and at relapse. All patients gave written informed consent to study inclusion. The study was approved by the local ethics committees in each country and conducted in accordance with the Declaration of Helsinki.

\subsection{Plasma sample analysis and data processing}

Heparin blood was shipped to Helsinki from the participating centres. Heparin plasma was obtained by centrifugation at $1300 \mathrm{~g}$ for 10 minutes in room temperature and immediately after collection, the plasma was stored in $-70^{\circ} \mathrm{C}$. Patient samples were analysed with Olink Proseek Multiplex (Olink Proteomics, Uppsala, Sweden). Two different panels were used, Inflammation I (INF I) and Oncology II (ONC II), each containing 92 inflammation- and cancer-related protein biomarkers, respectively (see Supplemental Tables A1 and A2 for a complete list of all biomarkers). Olink utilizes so called proximity extension assay (PEA) which is based on pairs of antibodies linked to oligonucleotides with a slight affinity to each other. When the antibodies bind to their target protein, the oligonucleotides are brought in proximity and extended by a DNA polymerase, forming a new sequence that acts as a surrogate marker for the antigen. The new sequence is then extended by qPCR and the copy numbers formed are proportional to the concentration of the antigen in the sample. ${ }^{15}$ Frozen aliquots of patient heparin plasma samples were shipped to Olink Proteomics and analysed there according to the laboratory's standard operating procedure. Samples were run in duplicates. The limit of detection (LOD) was defined as 3xSD above assay background and values below the LOD were replaced by the value for the LOD for statistical analyses. If many values are replaced by the 
LOD value the natural variation in the data for that analyte decreases, which might have an impact on the statistical analyses. In this study, a few analytes had a large amount of values below the LOD, and the rest of the analytes had very few of these values. Therefore, analytes with $\geq 25 \%$ of values below the LOD were excluded from statistical analyses. The remaining analytes all had less than $10 \%$ of values below the LOD. Proseek Multiplex uses relative quantification and data are presented as normalized protein expression (NPX), which is an arbitrary unit on log2 scale. Internal and external controls were included in each run. Coefficients of variation (CV) values were calculated using linearized values $\left(2^{\mathrm{NPX}}\right)$ in order to investigate platform performance, for all statistical analyses the log2 scale was used.

\subsection{Statistical analyses}

Statistical analyses were performed on log2 data which were approximately normally distributed. Welch's unequal variances t-test was used to determine statistically significant differences between groups (relapse vs. non-relapse). Linear Mixed Effects Modelling (LMM) ${ }^{16}$ was used to investigate differences between groups over time and the effect of time itself (longitudinal analyses) during the first 6 months. With LMM the within-individual correlations are taken into account, as well as the order of the time points, and the baseline value is allowed to vary between individuals (random intercept). The group effect relapse versus non-relapse is treated as a fixed effect, and a Toepliz within-individual correlation structure is being used which implies that the correlation between close time points may differ from the correlation between time points further apart. The mean protein levels are estimated by a linear trend over time, and these linear trends are compared between the two groups. The data does not suggest any particular trend pattern, which makes a linear trend a reasonable choice to summarize the effect of time. Analyses of the model residuals showed that the model fitted the data well for all the analytes.

All analyses were adjusted for multiple testing using the False Discovery Rate (FDR) method of correction. ${ }^{17}$ The false discovery rate is the proportion of "discoveries" (significant results) that are actually false positives. Since we have previously explored the effects of TKI treatment on plasma protein profiles ${ }^{14}$, we used a false discovery rate of $5 \%$ for analyses of TKI effects in treated patients. In the mixed effects model a false discovery rate of $10 \%$ was applied since this was considered an exploratory setting and positive results would have to be confirmed in follow-up studies which would reveal any false positives. Thus, using a false discovery rate of $10 \%$ is feasible in this situation. Statistical analyses were performed with R, SPSS Statistics v 23, and SAS v 9.4.

\section{Results}

\subsection{Platform performance and output}

On both panels, $98 \%$ of the samples met the quality control criteria. Intra-assay coefficient of variance (CV) values were $6 \%$ for both INF I and ONC II. Inter-assay CV values were $12 \%$ and $11 \%$ for INF I and ONC II, respectively. On the INF I panel, $76 \%$ of the analytes were detectable in $>75 \%$ of the samples. On the ONC II panel, all analytes were detectable in $>75 \%$ of the samples, rendering 162 evaluable proteins in total.

\subsection{Patient characteristics}

Patient characteristics are summarised in Table 1. The median (range) age at diagnosis was 53.3 (17.8-77.9) years. The male to female ratio was 31 to 25 . Sokal risk group distribution was as follows: 
$52 \%$ low risk (LR), $27 \%$ intermediate risk (IR), $16 \%$ high risk (HR) and $4 \%$ unknown. For the EUTOS score, $89 \%$ were LR, $7 \% \mathrm{HR}$ and $4 \%$ unknown. Thus, a slightly higher proportion of patients were low risk as compared to a population-based cohort. ${ }^{6}$

At diagnosis, patients were started on treatment with imatinib $(n=42)$, dasatinib $(n=11)$ or nilotinib $(n=3)$. At TKI stop, two patients had changed treatment from imatinib to dasatinib and two had changed from dasatinib to imatinib so that the frequencies of different treatments remained unchanged. Nine patients ( 5 in the relapse group and 4 in the non-relapse group) had been treated with interferon (IFN) alpha prior to TKI treatment. Median (range) age at TKI stop was 62.1 (23.583.7) years and median TKI treatment duration was 6.1 (3.1-12.3) years. After a median (range) follow up of 22.9 (7.3-38.5) months, 32 patients had relapsed as defined in the methods section. Twenty-four relapses occurred within the first six months (early) and eight thereafter (late). At relapse, all patients were re-started on TKI treatment. At the end of follow up, all 32 patients had regained $M M R$ and all but two had regained $M^{4.0}$.

\subsection{Relapse versus non-relapse}

At baseline, immediately prior to TKI discontinuation, no significant differences in protein levels were found by Welch's t-test between patients who later relapsed and those who remained in TFR. However, when analysing data over time after TKI discontinuation with the linear mixed model approach, some differences between groups could be seen. The analytes that differed between relapse and non-relapse cases were leukaemia inhibitory factor receptor (LIF-R; LMM estimate for relapse $-0.1838, p=0.0106$ ), IL-15 receptor alpha (IL-15R alpha; LMM estimate for relapse -0.2136 , $p=0.0235)$, colony stimulating factor- 1 (CSF-1; LMM estimate for relapse $-0.18679, p=0.0014$ ), transforming growth factor beta receptor type 2 (TGFR-2; LMM estimate for relapse -0.2672 , $p=0.0218$ ), stem cell factor (SCF; LMM estimate for relapse $-0.2221, p=0.0254$ ) and folate receptor (FR) alpha (LMM estimate for relapse $-0.2208, p=0.0257$ ) (Figure 1). Thus, a significant difference between group means could be seen over time, with non-relapse cases having higher group means for all analytes mentioned above. Individual patients' values were also compared to group means and related to relapse status. At the 1 month-time point, many relapse cases had values higher than the group means (between 31 and 55\% for the different analytes) and no clear cut off-value could be found to distinguish between relapse and non-relapse cases. At the 6 month-time point, a smaller proportion of relapse cases had values higher than the group means (between 13 and 38\%). For the LIF-R and TGFR-2, only one relapse case per analyte had a value above the group mean. However, no clear cut-off value separating relapse and non-relapse cases could be found at 6 months either.

Since most relapses after TKI discontinuation occur during the first 6 months, we were interested in finding possible biological differences between early (within the first six months) and late relapses. Results from baseline and month 1 for patients who relapsed were therefore compared between the two groups but no significant differences could be seen at any time point.

\subsection{Effects of TKI treatment}

Since imatinib and dasatinib are known to affect partly different signalling pathways ${ }^{18}$, we compared baseline values between these two groups. However, only a few proteins (monocyte chemotactic protein (MCP) 4, glypican-1 (GPC1), Erb B2, Erb B4, CD207; adjusted p-values <0.05; Figure 2) were significantly different between imatinib- and dasatinib-treated patients with values being higher in imatinib-treated patients for all differing analytes. 
After TKI discontinuation, an increase or decrease over time could be seen for a total of 39 proteins with the LMM analysis (Table 2), while the remaining analytes did not significantly change over the course of six months.

Since prior treatment with IFN alpha has been implicated to increase the probability of $\mathrm{TFR}^{19}$, we evaluated possible differences in protein levels between patients who had received IFN pretreatment at any time point and those who had not. With reservation for unequal group sizes, no significant differences in protein levels could be found at any time point between patients who had been previously treated with IFN alpha and those who had not received such treatment.

\section{Discussion}

Despite increasing knowledge about clinical and biological factors influencing the probability of TFR after TKI discontinuation, there is still a need for better prediction tools to guide clinical decision making when choosing patients for TKI stopping attempts. In the present study, we performed plasma proteomics on 56 patients discontinuing TKIs within the EURO-SKI trial with the aim of identifying potential plasma protein biomarkers for relapse after TKI discontinuation.

No plasma proteins were significantly different between relapse and non-relapse patients before stopping TKI treatment and thus, no predictive plasma protein markers for successful TKI discontinuation could be identified. Also after TKI discontinuation, only a few plasma proteins were significantly different between relapse and non-relapse cases, probably reflecting that the levels of disease at molecular relapse are low with a low mutational profile that does not evoke T-cell responses or profound effects on plasma cytokine levels. The fact that NK cell-based immunity, which is independent of the formation of new tumour antigens, has been shown to be important for TFR ${ }^{10}$ supports this theory. Nevertheless, six plasma proteins differed significantly between relapsing and non-relapsing patients after TKI discontinuation: LIF-R, IL-15R alpha, CSF-1, TGFR-2, SCF and FR alpha. The mean protein levels were higher in non-relapse cases for all analytes.

The LIF-R, upon binding of its ligand LIF, activates JAK/STAT and other signalling pathways. ${ }^{20}$ LIF-R has been shown to suppress metastasis of hepatocellular carcinoma and pancreatic cancer. ${ }^{21,22}$ However, in CML, STAT signalling has been connected to leukaemia initiation and maintenance ${ }^{23}$ as well as TKI resistance. ${ }^{24}$ Thus, the mechanisms behind our findings remain to be elucidated but might involve other signalling pathways than the JAK:STAT pathway in residual malignant cells or signalling in other cell types such as immune cells since LIF:LIF-R signalling plays an important role in T-cell immunity. ${ }^{20}$

IL-15R alpha is a sub-unit of the IL-15 receptor that binds IL-15 to the cell surface and thereby supports NK-cell development. ${ }^{25,26}$ Clinical trials using IL-15 alone or in combination with NK cells have shown beneficial effects in both solid tumours and haematological malignancies. ${ }^{27}$ We have previously shown that an increased proportion of mature NK cells was associated with successful imatinib discontinuation ${ }^{10}$ and our current finding of higher levels of IL-15R alpha in the nonrelapsing patients might offer support for the importance of NK cells in successful TFR.

CSF-1 (or M-CSF; macrophage-colony stimulating factor) is important for innate immunity by its regulation of the development of tissue macrophages. ${ }^{28}$ In solid cancers, the expression of CSF-1 and presence of tumour infiltrating macrophages have been linked to poor outcome ${ }^{29}$ while less is known about the role of CSF-1 in leukaemia. Imatinib has off-target effects on the receptor for CSF-1, the cfms. ${ }^{30}$ Thus, our findings are of unclear significance but could have potential explanations both in immunological functions and treatment effects.

TGFR-2 is the receptor for TGF $\beta$, which is a transcriptional regulator in hematopoietic cells and induces cell cycle arrest in primitive bone marrow progenitors. ${ }^{31} \mathrm{~A}$ study comparing the inhibitory 
effects of TGF $\beta$ on primitive hematopoetic cells from CML patients and healthy donors found that the CML progenitors were more sensitive to TGF $\beta$ mediated inhibition than their normal counterparts. ${ }^{32}$ Low levels of TGFR-2 have been found in both CML and other myeloproliferative neoplasms. ${ }^{33}$ Thus, one can speculate that the lower levels of TGFR-2 that we found in relapse cases might give a proliferative advantage to cells that escape the negative regulation of TGF $\beta$.

SCF, which is the ligand for receptor c-kit that is targeted by imatinib, has previously been implied in the pathogenesis of CML by inducing proliferation of $\mathrm{CD} 34+$ progenitors in vitro. ${ }^{34}$ However, SCF levels in serum from untreated CML patients are not different from healthy controls. ${ }^{35}$ Imatinib treatment has been shown to increase SCF in patients treated for gastrointestinal stromal tumours $(\text { GIST })^{36}$ and, in a pilot study evaluating the effects of TKI treatment on multiple plasma proteins in CML patients, we also found that SCF increased after treatment initiation. ${ }^{14}$ It is thus possible that the effect of SCF on CML cells is different in vitro and in vivo. The increase in SCF described after imatinib treatment might represent a compensatory mechanism to maintain normal c-kit related functions which might somehow be of importance for TFR.

FR alpha is increased in tumours of epithelial origin and might confer a growth advantage to the tumour by modulating folate uptake from serum. ${ }^{37} \mathrm{FR}$ alpha expression has not been extensively studied in CML or other haematological malignancies and its effects in CML are to our knowledge unknown. However, in our previous study referred above, FR alpha increased in CML patients after TKI treatment initiation.

In conclusion, only a few differences in protein levels were seen between non-relapsing and relapsing cases. No predictive protein biomarkers for successful TKI discontinuation could be found. It could be of interest to confirm the differences between relapse and non-relapse cases in an experimental setting or in a bigger cohort of patients, but it is likely that plasma protein markers alone are not sensitive enough to predict molecular relapse. It is plausible that several different clinical and biological factors will need to be combined for the best prediction of which patients will benefit most from TKI cessation attempts.

\section{Acknowledgements}

The authors would like to thank participating EURO-SKI centres and investigators.

\section{Funding}

Funding for this sub-study was supplied by the Nordic Cancer Union and Lions Uppsala.

\section{Appendix A. Supplementary data}

Supplemental tables $\mathrm{A} 1$ and $\mathrm{A} 2$.

\section{References}

1. Saussele S, Richter J, Guilhot J, et al. Discontinuation of tyrosine kinase inhibitor therapy in chronic myeloid leukaemia (EURO-SKI): a prespecified interim analysis of a prospective, multicentre, non-randomised, trial. Lancet Oncol 2018; 19(6): 747-57.

2. Faderl S, Talpaz M, Estrov Z, O'Brien S, Kurzrock R, Kantarjian HM. The Biology of Chronic Myeloid Leukemia. The New England Journal of Medicine 1999; 341(3): 164-72.

3. Hochhaus A, O'Brien SG, Guilhot F, et al. Six-year follow-up of patients receiving imatinib for the first-line treatment of chronic myeloid leukemia. Leukemia 2009; 23(6): 1054-61. 

chronic-phase chronic myeloid leukemia: 2-year follow-up from a randomized phase 3 trial (DASISION). Blood 2012; 119(5): 1123-9.

5. Saglio G, Kim DW, Issaragrisil S, et al. Nilotinib versus imatinib for newly diagnosed chronic myeloid leukemia. N Engl J Med 2010; 362(24): 2251-9.

6. Höglund M, Sandin F, Hellström K, et al. Tyrosine kinase inhibitor usage, treatment outcome, and prognostic scores in CML: report from the population-based Swedish CML registry. Blood 2013; 122(7): 1284-92.

7. Valent $P$, Hadzijusufovic $E$, Schernthaner $G-H$, Wolf $D$, Rea $D$, le Coutre $P$. Vascular safety issues in CML patients treated with BCR/ABL1 kinase inhibitors. Blood 2015; 125(6): 901-6. 8. Hughes TP, Ross DM. Moving treatment-free remission into mainstream clinical practice in CML. Blood 2016; 128(1): 17-23.

9. Schutz C, Inselmann S, Sausslele S, et al. Expression of the CTLA-4 ligand CD86 on plasmacytoid dendritic cells $(\mathrm{pDC})$ predicts risk of disease recurrence after treatment discontinuation in CML. Leukemia 2017; 31(4): 829-36.

10. Ilander M, Olsson-Stromberg $\mathrm{U}$, Schlums $\mathrm{H}$, et al. Increased proportion of mature NK cells is associated with successful imatinib discontinuation in chronic myeloid leukemia. Leukemia 2016; 31(5): 1108-16.

11. Caocci G, Martino B, Greco M, et al. Killer immunoglobulin-like receptors can predict TKI treatment-free remission in chronic myeloid leukemia patients. Exp Hematol 2015; 43(12): 10158 e1.

12. Smirnikhina SA, Lavrov AV, Chelysheva EY, et al. Whole-exome sequencing reveals potential molecular predictors of relapse after discontinuation of the targeted therapy in chronic myeloid leukemia patients. Leukemia \& lymphoma 2016; 57(7): 1669-76.

13. Caocci G, Greco M, Delogu G, et al. Telomere length shortening is associated with treatment-free remission in chronic myeloid leukemia patients. Journal of hematology \& oncology 2016; 9(1): 63.

14. Soderlund S, Christiansson L, Persson I, et al. Plasma proteomics in CML patients before and after initiation of tyrosine kinase inhibitor therapy reveals induced Th1 immunity and loss of angiogenic stimuli. Leuk Res 2016; 50: 95-103.

15. Assarsson $\mathrm{E}$, Lundberg $\mathrm{M}$, Holmquist $\mathrm{G}$, et al. Homogenous 96-plex PEA immunoassay exhibiting high sensitivity, specificity, and excellent scalability. PloS one 2014; 9(4): e95192.

16. Laird NM, Ware JH. Random-effects models for longitudinal data. Biometrics 1982; 38(4): 963-74.

17. Benjamini Y, Hochberg Y. Controlling the False Discovery Rate: A Practical and Powerful Approach to MultipleTesting. Journal of the Royal Statistical Society 1995; 57(1): 289-300. 18. Druker BJ. Translation of the Philadelphia chromosome into therapy for CML. Blood 2008; 112(13): 4808-17.

19. Ross DM, Hughes TP. How I determine if and when to recommend stopping tyrosine kinase inhibitor treatment for chronic myeloid leukaemia. British journal of haematology 2014; 166(1): 3-11.

20. Metcalfe SM. LIF in the regulation of T-cell fate and as a potential therapeutic. Genes Immun 2011; 12(3): 157-68.

21. Luo $Q$, Wang $C$, Jin $G$, et al. LIFR functions as a metastasis suppressor in hepatocellular carcinoma by negatively regulating phosphoinositide 3-kinase/AKT pathway. Carcinogenesis 2015; 36(10): 1201-12.

22. Ma D, Jing $X$, Shen $B$, et al. Leukemia inhibitory factor receptor negatively regulates the metastasis of pancreatic cancer cells in vitro and in vivo. Oncology reports 2016; 36(2): 827-36. 23. Hoelbl A, Schuster C, Kovacic B, et al. Stat5 is indispensable for the maintenance of bcr/abl-positive leukaemia. EMBO Mol Med 2010; 2(3): 98-110. 

chronic myeloid leukemia and their relation to imatinib therapy. Leukemia Research 2014; 38(2): 243-50.

25. Huntington ND, Legrand N, Alves NL, et al. IL-15 trans-presentation promotes human NK cell development and differentiation in vivo. J Exp Med 2009; 206(1): 25-34.

26. Tamzalit F, Barbieux I, Plet A, et al. IL-15.IL-15Ralpha complex shedding following trans-presentation is essential for the survival of IL-15 responding NK and T cells. Proceedings of the National Academy of Sciences of the United States of America 2014; 111(23): 8565-70.

27. Decot V, Xiong Y, Bensoussan D. IL-15 as a potential target in leukemia. Blood and Lymphatic Cancer: Targets and Therapy 2015: 55.

28. Stanley ER, Chitu V. CSF-1 receptor signaling in myeloid cells. Cold Spring Harbor perspectives in biology 2014; 6(6).

29. Ries CH, Hoves S, Cannarile MA, Ruttinger D. CSF-1/CSF-1R targeting agents in clinical development for cancer therapy. Curr Opin Pharmacol 2015; 23: 45-51.

30. Dewar AL, Cambareri AC, Zannettino AC, et al. Macrophage colony-stimulating factor receptor c-fms is a novel target of imatinib. Blood 2005; 105(8): 3127-32.

31. Fortunel NO, Hatzfeld JA, Monier MN, Hatzfeld A. Control of hematopoietic stem/progenitor cell fate by transforming growth factor-beta. Oncology research 2003; 13(6-10): 445-53.

32. Foglia M, Carlo-Stella C, Curtia A, et al. Transforming growth factorb3 inhibits chronic myelogenous leukemia hematopoiesis by inducing Fas-independent apoptosis. Experimental Hematology 2000; 28(7).

33. Rooke H, Vitas M, Crosier P, Crosier K. The TGF-b type II receptor in chronic myeloid leukemia: analysis of microsatellite regions and gene expression. Leukemia 1999; 13(4).

34. Moore S, Haylock D, Lévesque J, et al. Stem Cell Factor as a Single Agent Induces Selective Proliferation of the Philadelphia Chromosome Positive Fraction of Chronic Myeloid Leukemia CD341 Cells. Blood 1998; 92(7): 2461-70.

35. Tao M, Li B, Nayini J, et al. SCF, IL-1beta, IL-1ra and GM-CSF in the bone marrow and serum of normal individuals and of AML and CML patients. Cytokine 2000; 12(6): 699-707.

36. Bono P, Krause A, von Mehren M, et al. Serum KIT and KIT ligand levels in patients with gastrointestinal stromal tumors treated with imatinib. Blood 2004; 103(8): 2929-35.

37. Kelemen LE. The role of folate receptor alpha in cancer development, progression and treatment: cause, consequence or innocent bystander? International journal of cancer Journal international du cancer 2006; 119(2): 243-50. 
Tables and figures

Table 1. Patient characteristics $(\mathrm{N}=56)$

\begin{tabular}{|c|c|}
\hline Age at diagnosis (years) & $53.3(17.8-77.9)$ \\
\hline Age at stop (years) & $62.1(23.5-83.7)$ \\
\hline \multicolumn{2}{|l|}{$\operatorname{Sex}(N(\%))$} \\
\hline Female & $25(45)$ \\
\hline Male & $31(55)$ \\
\hline \multicolumn{2}{|l|}{ Sokal score (N (\%)) } \\
\hline$L R$ & $29(52)$ \\
\hline IR & $15(27)$ \\
\hline$H R$ & $9(16)$ \\
\hline Missing & $2(4)$ \\
\hline \multicolumn{2}{|l|}{ EUTOS score (N (\%)) } \\
\hline$L R$ & $50(89)$ \\
\hline$H R$ & $4(7)$ \\
\hline Missing & $2(4)$ \\
\hline \multicolumn{2}{|l|}{ First TKI (N (\%)) } \\
\hline Ima & $42(75)$ \\
\hline Dasa & $11(20)$ \\
\hline Nilo & $3(5)$ \\
\hline \multicolumn{2}{|l|}{ TKI at stop ( $N(\%))$} \\
\hline Ima & $42(75)$ \\
\hline Dasa & $11(20)$ \\
\hline Nilo & $3(5)$ \\
\hline Total TKI duration at stop (years) & $6.1(3.1-12.3)$ \\
\hline Relapse, total (N (\%)) & $32(57)$ \\
\hline Relapse, early ( $\leq 6$ months) ( $N(\%))$ & $24(75)$ \\
\hline$B C R-A B L 1 \geq 1 \%$ at relapse $(N(\%))$ & $3(9)$ \\
\hline Regained MMR after TKI re-initiation (N (\%)) & $32(100)$ \\
\hline Regained MR4. 0 after TKI re-initiation (N (\%)) & $30(94)$ \\
\hline
\end{tabular}


Table 2. Plasma protein changes over time after TKI discontinuation.

\begin{tabular}{|c|c|c|c|c|}
\hline Protein & $\begin{array}{r}\text { LMM estimate } \\
\text { month }\end{array}$ & $\begin{array}{r}\text { Lower } \\
95 \% \mathrm{CL}\end{array}$ & $\begin{array}{r}\text { Upper } \\
95 \% \mathrm{CL}\end{array}$ & $\begin{array}{l}\text { P-value } \\
\text { (unadjusted) }\end{array}$ \\
\hline Hepatocyte growth factor (HGF) & 0.05009 & 0.007848 & 0.09233 & 0.0016 \\
\hline $\begin{array}{l}\text { Eucaryotic translation initiation factor } 4 \mathrm{E} \text {-binding } \\
\text { protein } 1 \text { (4E-BP1) }\end{array}$ & 0.03773 & -0.02801 & 0.1035 & 0.0131 \\
\hline $\begin{array}{l}\text { Delta and notch-like epidermal growth factor- } \\
\text { related receptor (DNER) }\end{array}$ & 0.00803 & -0.00618 & 0.02224 & 0.0057 \\
\hline CD40 & 0.03106 & -0.00372 & 0.06585 & 0.0111 \\
\hline 5' nucleotidase (5-NT) & 0.03020 & -0.00573 & 0.06613 & 0.0320 \\
\hline Adenosine Deaminase (ADA) & 0.04524 & 0.01808 & 0.07240 & $<.0001$ \\
\hline Annexin 1 (ANXA1) & 0.04215 & -0.02057 & 0.1049 & 0.0089 \\
\hline C-X-C motif chemokine 13 (CXCL13) & 0.05079 & 0.006012 & 0.09557 & 0.0142 \\
\hline Carbonic anhydrase 9 (CA9) & -0.06850 & -0.1178 & -0.01925 & 0.0002 \\
\hline Carboxypeptidase E (CPE) & -0.02186 & -0.04436 & 0.000638 & 0.0007 \\
\hline $\begin{array}{l}\text { Disintegrin and metalloproteinase domain- } \\
\text { contacting protein } 8 \text { (ADAM-8) }\end{array}$ & 0.03020 & -0.00573 & 0.06613 & 0.0320 \\
\hline Epidermal growth factor (EGF) & 0.03004 & -0.03263 & 0.09272 & 0.0017 \\
\hline FC-receptor-like B (FCRLB) & -0.01600 & -0.03981 & 0.007811 & 0.0022 \\
\hline Fasantigen ligand (FasL) & 0.02967 & 0.01057 & 0.04877 & $<.0001$ \\
\hline $\begin{array}{l}\text { Fibroblast growth factor-binding protein } 1 \text { (FGF- } \\
\text { BP1) }\end{array}$ & -0.02240 & -0.04886 & 0.004050 & 0.0008 \\
\hline Folate receptor alpha (FR alpha) & -0.02230 & -0.04214 & -0.00247 & 0.0036 \\
\hline Fractalkine (CX3CL1) & -0.03501 & -0.05676 & -0.01327 & 0.0096 \\
\hline Furin & 0.02235 & 0.000552 & 0.04414 & 0.0023 \\
\hline Galectin 1 (Gal-1) & 0.01812 & 0.005558 & 0.03069 & 0.0234 \\
\hline Hepatocyte growth factor (HGF) & 0.05009 & 0.007848 & 0.09233 & 0.0016 \\
\hline ICOS ligand (ICOSLG) & 0.01673 & 0.001090 & 0.03237 & 0.0040 \\
\hline Integrin beta-5 (ITGB5) & 0.01451 & -0.00780 & 0.03681 & 0.0203 \\
\hline Interleukin 10 receptor subunit beta (IL10 RB) & 0.02328 & 0.006953 & 0.03961 & $<.0001$ \\
\hline Interleukin 18 receptor 1 (IL18 R1) & 0.02000 & -0.00229 & 0.04229 & 0.0008 \\
\hline Kallikrein 14 (hK14) & -0.01090 & -0.04234 & 0.02053 & 0.0139 \\
\hline Matrix metalloproteinase 10 (MMP10) & -0.05329 & -0.08039 & -0.02620 & 0.0004 \\
\hline $\begin{array}{l}\text { Proto-oncogene tyrosine-protein kinase receptor } \\
\text { (RET) }\end{array}$ & 0.13607 & 0.09343 & 0.1787 & $<.0001$ \\
\hline
\end{tabular}




\begin{tabular}{|l|r|r|r|l|}
\hline Protein & $\begin{array}{r}\text { LMM estimate } \\
\text { month }\end{array}$ & $\begin{array}{r}\text { Lower } \\
95 \% \text { CL }\end{array}$ & $\begin{array}{r}\text { Upper } \\
95 \% \text { CL }\end{array}$ & $\begin{array}{l}\text { P-value } \\
\text { (unadjusted) }\end{array}$ \\
\hline Receptor tyrosine-protein kinase (Erb-B2) & 0.00834 & -0.00691 & 0.02358 & 0.0068 \\
\hline S100-A12 (EN-RAGE) & 0.07587 & -0.00169 & 0.1534 & 0.0027 \\
\hline TNF-related apoptosis-inducing ligand (TRAIL) & 0.02462 & 0.009219 & 0.04001 & $<.0001$ \\
\hline TNFRSF1919 & 0.05662 & 0.03045 & 0.08278 & $<.0001$ \\
\hline Tissue factor pathway inhibitor 2 (TFPI2) & -0.01954 & -0.04471 & 0.005625 & 0.0062 \\
\hline Toll-like receptor 3 (TLR3) & 0.04275 & 0.01960 & 0.06589 & $<.0001$ \\
\hline Transforming growth factor alpha (TGF alpha) & 0.07339 & 0.000477 & 0.1463 & 0.0075 \\
\hline $\begin{array}{l}\text { Transforming growth factor beta receptor type 2 } \\
\text { (TGFR2) }\end{array}$ & 0.02914 & 0.008093 & 0.05019 & 0.0226 \\
\hline $\begin{array}{l}\text { Tumour necrosis factor (TNF) receptor } \\
\text { superfamily member 9 (TNFRSF) }\end{array}$ & 0.03568 & 0.008146 & 0.06322 & 0.0001 \\
\hline Vascular endothelial growth factor A (VEGF-A) & 0.02176 & -0.00999 & 0.05352 & 0.0047 \\
\hline $\begin{array}{l}\text { WNT1-inducible signalling pathway protein 1 } \\
\text { (WISP-1) }\end{array}$ & 0.10061 & 0.07561 & 0.1256 & $<.0001$ \\
\hline s100-A11 & 0.03298 & -0.03280 & 0.09876 & 0.0006 \\
\hline
\end{tabular}

The estimate for month denotes the average slope of the linear trend over time, i.e. how much the average protein value changes over one month (a positive value indicates an increase over time). A false discovery rate of $10 \%$ was applied. All pvalues presented in the table remained significant after FDR correction. 

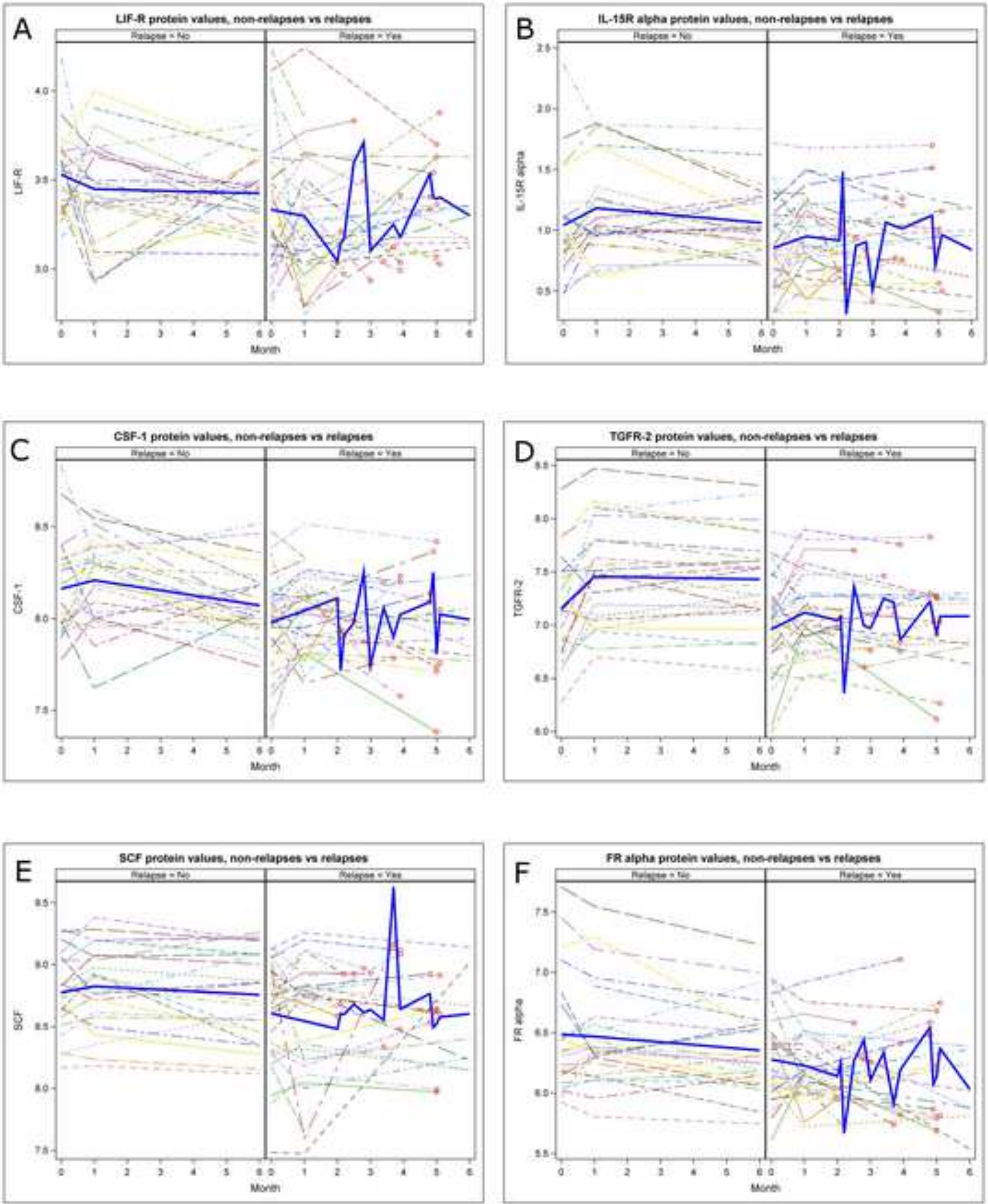

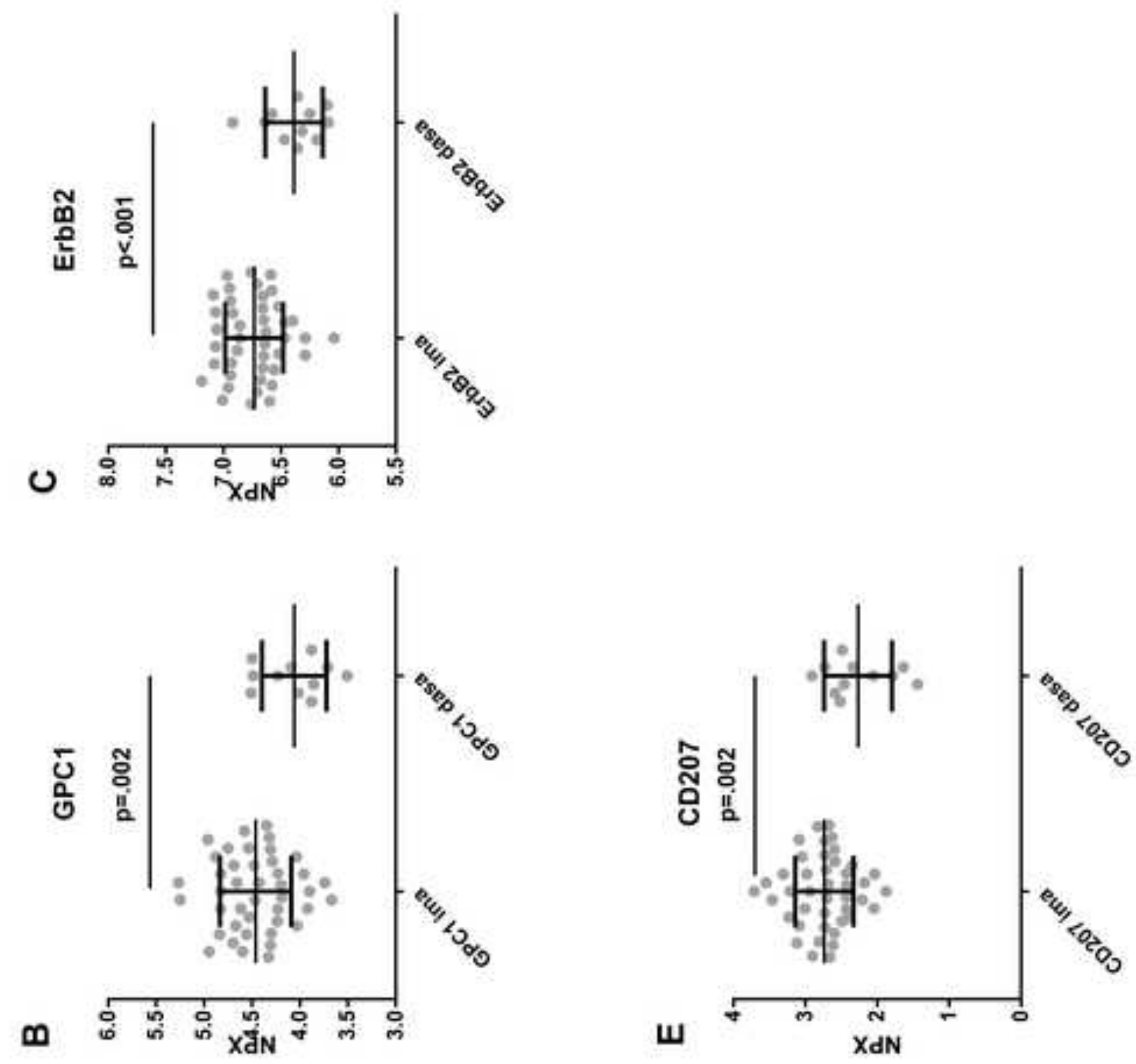

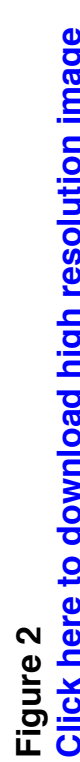

Figure 1. Proteins significantly different between non-relapse and relapse cases. The mean protein levels were estimated by a linear trend over time, and these linear trends were compared between the two groups in a linear mixed effects model. The mean protein levels are displayed as a solid blue line while individual patient values are shown in dotted coloured lines. Red circles indicate where relapses occurred. A false discovery rate of $10 \%$ was applied. A) Leukaemia inhibitory factor receptor (LIF-R), B) IL-15 receptor alpha C) Colony stimulating factor 1 (CSF-1), D) Transforming growth factor beta receptor type 2 (TGFR-2), E) Stem cell factor (SCF) and F) Folate receptor alpha (FR alpha).

Figure 2. Proteins significantly different between imatinib and dasatinib treated patients. Thin vertical lines represent mean values and error bars represent the standard deviation. A) Monocyte chemotactic protein 4 (MCP4), B) Glypican-1 (GPC-1), C) ErbB2, D) ErbB4, E) CD207. 


\section{${ }^{\star}$ Acknowledgements}

\section{Acknowledgements}

The authors would like to thank participating EURO-SKI centres and investigators. Funding for this sub-study was supplied by the Nordic Cancer Union and Lions Uppsala. 
Declaration of interests:

Stina Söderlund: none

Inger Persson: none

Mette llander: none

Joëlle Guilhot: none

Henrik Hjorth-Hansen: none

Perttu Koskenvesa: reports receiving lecture fees from Incyte

Johan Richter: none

Susanne Saussele: reports honoraria from Novartis, BMS, Incyte, Pfizer and research support from BMS, Novartis and Incyte

Satu Mustjoki: reports research funding from BMS, Novartis and Pfizer and honoraria from BMS

Ulla Olsson-Strömberg: none 


\section{Appendix A. Supplementary data}

Supplemental Table A1. All analytes, Inflammation I.

\begin{tabular}{|c|c|c|}
\hline Adenosine Deaminase (ADA) & FGF-23 & $\begin{array}{l}\text { Monocyte chemotactic protein } \\
\text { (MCP)-1 }\end{array}$ \\
\hline Artemin (ARTN) & $\begin{array}{l}\text { Fms-like tyrosine kinase } 3 \\
\text { ligand (Flt3L) }\end{array}$ & MCP-2 \\
\hline Axin-1 & $\begin{array}{l}\text { Glial cell line-derived } \\
\text { neurotropic factor (GDNF) }\end{array}$ & MCP-3 \\
\hline $\begin{array}{l}\text { Brain-derived neurotropic } \\
\text { factor (BDNF) }\end{array}$ & $\begin{array}{l}\text { Hepatocyte growth factor } \\
\text { (HGF) }\end{array}$ & $\mathrm{MCP}-4$ \\
\hline $\begin{array}{l}\text { Beta-nerve growth factor } \\
\text { (Beta-NGF) }\end{array}$ & Interferon (IFN)-gamma & $\begin{array}{l}\text { Macrophage inflammatory } \\
\text { protein (MIP)-1 alpha }\end{array}$ \\
\hline Caspase (CASP)-8 & Interleukin (IL)-1-alpha & $\begin{array}{l}\text { Matrix metalloproteinase } \\
\text { (MMP)-1 }\end{array}$ \\
\hline C-C motif chemokine (CCL)4 & IL-2 & MMP-10 \\
\hline CCL11 & IL-4 & Neurturin (NRTN) \\
\hline CCL19 & IL-5 & Neurotrophin (NT)-3 \\
\hline CCL20 & IL-6 & Osteoprotegerin (OPG) \\
\hline CCL23 & IL-7 & Oncostatin-M (OSM) \\
\hline CCL25 & IL-8 & $\begin{array}{l}\text { Programmed death ligand } 1 \\
\text { (PD-L1) }\end{array}$ \\
\hline CCL28 & IL-10 & Stem cell factor (SCF) \\
\hline Cluster of differentiation (CD)5 & IL-12B & SIR2-like protein 2 (SIRT2) \\
\hline CD6 & IL-13 & $\begin{array}{l}\text { Signaling lymphocytic } \\
\text { activation molecule } 1 \\
\text { (SLAMF1) }\end{array}$ \\
\hline CD40 & IL-17A & $\begin{array}{l}\text { STAM-binding protein } \\
\text { (STAMPB) }\end{array}$ \\
\hline CD244 & IL-17C & Sulfotransferanse (ST)1A1 \\
\hline $\begin{array}{l}\text { CUB domain-containing } \\
\text { protein } 1 \text { (CDCP1) }\end{array}$ & IL-18 & S100-A12 (EN-RAGE) \\
\hline $\begin{array}{l}\text { Colony stimulating factor } \\
\text { (CSF)-1 }\end{array}$ & IL-20 & $\begin{array}{l}\text { Transforming growth factor } \\
\text { (TGF)-alpha }\end{array}$ \\
\hline Cystatin D (CST5) & IL-24 & Tumour necrosis factor (TNF) \\
\hline C-X-C motif chemokine(CXCL)1 & IL-33 & TNFB \\
\hline CXCL5 & IL-2 receptor $(R) B$ & $\begin{array}{l}\text { TNF-receptor superfamily } \\
\text { member } 9 \text { (TNFRSF9) }\end{array}$ \\
\hline CXCL6 & IL-10RA & $\begin{array}{l}\text { TNF-ligand superfamily } \\
\text { member } 14 \text { (TNFSF14) }\end{array}$ \\
\hline CXCL9 & IL-10RB & $\begin{array}{l}\text { TNF-related apoptosis-inducing } \\
\text { ligand (TRAIL) }\end{array}$ \\
\hline CXCL10 & IL-15RA & $\begin{array}{l}\text { TNF-related activation-induced } \\
\text { cytokine (TRANCE) }\end{array}$ \\
\hline CXCL11 & IL-18R1 & $\begin{array}{l}\text { Thymic stromal lymphopoietin } \\
\text { (TSLP) }\end{array}$ \\
\hline Fractalkine (CX3CL1) & IL-20RA & $\begin{array}{l}\text { TNF-ligand superfamily } \\
\text { member } 12 \text { (TWEAK) }\end{array}$ \\
\hline $\begin{array}{l}\text { Delta- and notch-like } \\
\text { epidermal growth factor- }\end{array}$ & IL-22-RA1 & $\begin{array}{l}\text { Urokinase-type plasminogen } \\
\text { activator (UPA) }\end{array}$ \\
\hline
\end{tabular}




\begin{tabular}{|l|l|l|}
\hline related receptor (DNER) & & \\
\hline $\begin{array}{l}\text { Fibroblast growth factor (FGF)- } \\
5\end{array}$ & $\begin{array}{l}\text { Latency associated peptide } \\
\text { transforming growth factor } \\
\text { (LAP TGF)-beta-1 }\end{array}$ & $\begin{array}{l}\text { Vascular endothelial growth } \\
\text { factor (VEGF)-A }\end{array}$ \\
\hline FGF-19 & Leukemia inhibitory factor (LIF) & $\begin{array}{l}\text { Eucaryotic translation initiation } \\
\text { factor 4E-binding protein (4E- } \\
\text { BP1) }\end{array}$ \\
\hline FGF-21 & LIF-R & \\
\hline
\end{tabular}

Supplemental Table A2. All analytes, Oncology II.

\begin{tabular}{|c|c|c|}
\hline $\begin{array}{l}\text { Tyrosine-protein kinase } 1 \\
\text { (ABL1) }\end{array}$ & Folate receptor (FR)-alpha & $\begin{array}{l}\text { Proto-oncogene tyrosine- } \\
\text { protein kinase receptor Ret } \\
\text { (RET) }\end{array}$ \\
\hline $\begin{array}{l}\text { A disintegrin and } \\
\text { metalloproteinase domain- } \\
\text { containing protein (ADAM) } 8\end{array}$ & FR-gamma & R-spondin 3 (RSPO3) \\
\hline $\begin{array}{l}\text { A disintegring and } \\
\text { metalloproteinase with } \\
\text { thrombospondin motifs } \\
\text { (ADAM-TS) } 15\end{array}$ & Furin (FUR) & $\begin{array}{l}\text { Secretory carrier-associated } \\
\text { membrane protein } 3 \text { (SCAMP3) }\end{array}$ \\
\hline Annexin A1 (ANXA1) & Galectin (Gal)-1 & SCF \\
\hline Amphiregulin (AR) & Glypican 1 (GPC1) & Seizure 6-like protein (SEZ6L) \\
\hline Carbonic anhydrase (CA)9 & Glycoprotein NMB (GPNMB) & SPARC \\
\hline CD27 & Granzyme (GZM)B & Syndecan 1 (SYND1) \\
\hline CD48 & GZMH & S100-A4 \\
\hline CD70 & Kallikrein (hK)8 & S100-A11 \\
\hline CD160 & hK11 & $\begin{array}{l}\text { T cell leukemia/lymphoma } \\
\text { protein }(\mathrm{TCL}) 1 \mathrm{~A}\end{array}$ \\
\hline CD207 & hK14 & $\begin{array}{l}\text { Tissue factor pathway inhibitor } \\
\text { (TFPI)-2 }\end{array}$ \\
\hline $\begin{array}{l}\text { Cyclin-dependent kinase } \\
\text { inhibitor } 1 \text { (CDKN1A) }\end{array}$ & ICOS ligand (ICOSLG) & TGF-alpha \\
\hline $\begin{array}{l}\text { Carcinoembryotic antigen- } \\
\text { related cell adhesion molecule } \\
\text { (CEACAM)1 }\end{array}$ & IFN-gamma-R1 & TGFR-2 \\
\hline CEACAM5 & $\begin{array}{l}\text { Insuline-like growth factor } 1 \\
\text { receptor (IGF1R) }\end{array}$ & Toll-like receptor (TLR)3 \\
\hline Carboxypeptidase E (CPE) & $\mathrm{IL}-6$ & TNFSF13 \\
\hline Cornulin (CRNN) & Integrin alpha-V (ITGAV) & TNFRSF4 \\
\hline Cathepsin L2 (CTSV) & Integrin beta-5 (ITGB5) & TNFRSF6B \\
\hline CXCL13 & Kallikrein (KLK)13 & TNFRSF19 \\
\hline CXL17 & $\begin{array}{l}\text { Tyrosine-protein kinase Lyn } \\
\text { (LYN) }\end{array}$ & TRAIL \\
\hline $\begin{array}{l}\text { Cysteine-rich angiogenic } \\
\text { inducer (CYR)61 }\end{array}$ & $\begin{array}{l}\text { Ly6/PLAUR domain-containing } \\
\text { protein } 3 \text { (LYPD3) }\end{array}$ & Taxilin alpha (TXLNA) \\
\hline Delta-like protein 1 (DLL1) & Lymphocyte antigen 9 (LY9) & VEGF-A \\
\hline
\end{tabular}




\begin{tabular}{|l|l|l|}
\hline Epidermal growth factor (EGF) & $\begin{array}{l}\text { Mothers against } \\
\text { decapentapleic (MAD) } \\
\text { homolog 5 }\end{array}$ & VEGFR-2 \\
\hline $\begin{array}{l}\text { Ephrin-type A receptor 2 } \\
\text { (EPHA2) }\end{array}$ & $\begin{array}{l}\text { Methionine aminopeptidase } \\
\text { (MetAP) 2 }\end{array}$ & VEGFR-3 \\
\hline $\begin{array}{l}\text { Endothelial cell-specific } \\
\text { molecule (ESM-)1 }\end{array}$ & $\begin{array}{l}\text { Melanoma-derived growth } \\
\text { regulatory protein (MIA) }\end{array}$ & Vimentin (VIM) \\
\hline $\begin{array}{l}\text { Receptor protein-tyrosine } \\
\text { kinase ErbB (ERBB)2 }\end{array}$ & $\begin{array}{l}\text { MHC class I polypeptide- } \\
\text { related sequence A/B (MIC- } \\
\text { A/B) }\end{array}$ & $\begin{array}{l}\text { WAP four-disulfide core } \\
\text { domain protein (WFDC)2 }\end{array}$ \\
\hline ERBB3 & Midkine (MK) & Wnt inhibitory facot (WIF)-1 \\
\hline ERBB4 & Mesothelin (MSLN) & $\begin{array}{l}\text { Wnt1-inducible-signaling } \\
\text { pathway protein (WISP)-1 }\end{array}$ \\
\hline $\begin{array}{l}\text { Fas-associated death domain } \\
\text { protein (FADD) }\end{array}$ & Mucin (MUC)-16 & $\begin{array}{l}\text { Xaa-pro aminopeptidase 2 } \\
\text { (XPNPEP2) }\end{array}$ \\
\hline Fas antigen-ligand (FASL) & Podocalyxin (PODXL) & 5' nucleotidase (5'-NT) \\
\hline Fc-receptor-like B (FCRLB) & Pancreatic pro-hormone (PPY) & \\
\hline $\begin{array}{l}\text { Fibroblast growth factor- } \\
\text { binding protein 1 (FGF-BP1) }\end{array}$ & Nectin-4 (PVRL4) & \\
\hline
\end{tabular}

